\title{
FAKTOR-FATOR YANG MEMPENGARUHI WISATAWAN MENGUNJUNGI PANTAI ZAKAT DI KOTA BENGKULU
}

\author{
Syamsul Huda, Jalal Ikhwan \\ Universitas Prof. Dr. Hazarin, SH. Bengkulu \\ samsulhuda1954@gmail.com dan Jalal_ikhwan@yahoo.com
}

\begin{abstract}
ABSTRAK
Syamsul Huda, Jalal Ikhwan; Tujuan penelitian ini adalah untuk mengetahui pengaruh keamanan, kenyamanan, informasi, fasilitas dan layanan terhadap wisatawan Rumah Pengasingan Bung Karno di Bengkulu. Penelitian ini menggunakan analisis kuantitatif dan kualitatif. Analisis kuantitatif menggunakan regresi linear berganda. Hasil perhitungan diperoleh nilai konstanta 4,314, keamanan ( $\left.\mathrm{X}_{1}\right)$ $=0,327$, kenyamanan $\left(\mathrm{X}_{2}\right)=0,127$, informasi $\left(\mathrm{X}_{3}\right)=0,201$, fasilitas $\left(\mathrm{X}_{4}\right)=0,272$ dan layanan pengelola $\left(\mathrm{X}_{5}\right)=0,400$. Nilai koefisien korelasi $(\mathrm{R})$ sebesar 0,767 dan koefisien determinasi $\left(\mathrm{R}^{2}\right)$ sebesar 0,588 ,

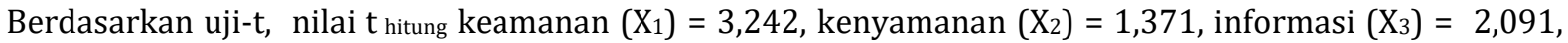
fasilitas $\left(X_{4}\right)=2,992$ dan layanan para pengelola $\left(X_{5}\right)=4,390$ dengan $t$ tabel sebesar 1,668 . Hasil uji $F$ diperoleh nilai $\mathrm{F}_{\text {hitung }}=18,813>\mathrm{F}$ tabel $=2,35$ yang berarti secara bersama-sama berpengaruh signifikan terhadap kuat terhadap kepuasan wisatawan (Y).
\end{abstract}

\section{ABSTRACT}

Syamsul Huda, Jalal Ikhwan; The research aims to determine the number of variables that affect tourists visiting Zakat beach in Bengkulu city. The population used is the visitors who visit Zakat beach. The type of data implemented is the primery daya. The way of implement it is by spreading out of questioners. The research puts on two variables. First, it is the independent variable. It consist of servicing, the trimming of the facilities, safety and earning. Where as the dependent variables focuses on the readability of the visitors to visit Zakat beach. The test stage are done by utilizing spss. To create the hypothesis test stages, it can apply the multiple regression model and t-statistic test. Building upon the hypothesis test result, it has been uncovered that the quality of servicing and safety have significant effects to the readibility of the visitors to come to see Zakat beach in Bengkulu city of Bengkulu province. It can be concluded that the trimming of the facility and earnings do not make significant effects towards the viusitors readability to pay a visit to Zakat beach.

Key Words: Service, Facilities, Security and Income.

\section{LATAR BELAKANG}

Pariwisata merupakan salah satu sumber devisa negara selain dari sektor migas yang sangat potensial dan mempunyai andil besar dalam membangun perekonomian yang saat ini pertumbuhannya masih sangat lambat. Sektor pariwisata di Indonesia masih bisa untuk dikembangkan dengan lebih maksimal lagi. Pengembangan sektor pariwisata yang dilakukan dengan baik akan mampu menarik wisatawan domestik maupun wisatawan asing untuk datang dan membelanjakan uangnya dalam kegiatan berwisatanya. Dari transaksi itulah masyarakat daerah wisata akan terangkat taraf hidupnya serta negara akan mendapat devisa dari wisatawan asing yang menukar mata uang negaranya dengan rupiah.

Objek wisata merupakan produk jasa yang ditawarkan oleh suatu perusahaan jasa dengan harapan agar konsumen datang untuk berkunjung dan menikmati objek wisata yang ditawarkan. Untuk dapat menarik kepuasan konsumen, pengelola harus dapat memberikan kualitas pelayanan yang terbaik untuk menciptakan suatu kepuasan konsumen. Dalam kondisi persaingan yang semakin ketat, hal utama yang harus diperhatikan oleh objek wisata adalah kualitas objek wisata, serta pengaruhnya terhadap kepuasan wisatawan agar dapat tetap bertahan, dan menguasai objek wisata.

Dalam kaitannya dengan pelayanan kepada wisatawan, pihak yang bergerak dalam pemberian pelayanan harus menyadari bahwa keberadaan wisatawan merupakan pendukung kesuksesan objek wisata. Dengan demikian mereka harus menempatkan wisatawan sebagai aset yang berharga, karena tidak ada satupun objek wisata yang akan beratahan bila tidak ada pengunjungnya.

Kualitas objek wisata yang baik merupakan daya tarik besar bagi wisatawan, sehingga dapat digunakan sebagai alat promosi untuk menarik minat wisatawan. Kualitas objek wisata dan pelayanan berpusat pada upaya pemenuhan kebutuhan dan keinginan wisatawan untuk mencapai suatu kepuasan tersendiri.Dalam persaingan banyaknya objek wisata, yang harus dperhatikan adalah kualitas objek 
wisata dan pelayanan yang diinginkan oleh wisatawan, sehingga jaminan kualitas menjadi prioritas utama bagi setiap objek wisata saat ini, khususnya sebagai tolak ukur adalah keunggulan daya saing terhadap objek wisata yang ada.

Kualitas objek wisata dapat diukur dari lima dimensi yaitu: rasa aman (perasaan wisatawan atas situasi dan kondisi keamanan selama berwisata, sebagai manifestasi intensitas layanan keamanan wisatawan dari pihak penyedia selama berekreasi disuatu destinasi), rasa nyaman (perasaan wisatawan atas kenyamanan lingkungan daerah wisata selama berekreasi, sebagai manifestasi intensitas kualitas pelayanan kenyamanan yang telah diberikan penyedia untuk wisatawan selama berwisata), kualitas penyajian informasi wisata (penilaian wisatawan terhadap kualitas pelayanan penyediaan dalam penyajian informasi wisata kesuatu daerah wisata), kelengkapan fasilitas objek wisata yang berkualitas (penilaian wisatawan terhadap intensitas usaha penyedia dalam menyediakan peralatan dan perlengkapan fisik rekreasi yang berkualitas di suatu daerah wisata), tingkat keterampilan komunikasi para petugas (penilaian wisata atas kemampuan para petugas dalam berkomunikasi dengan wisatawan selama berekreasi di suatu daerah wisata).

Rumah Pengasingan Bung Karno merupakan tempat Soekarno menjalani hukuman pengasingan sebagai tahanan politik. Rumah ini terletak di tengah Kota Bengkulu, tepatnya di jalan Sukarno Hatta Kelurahan Anggut Atas kecamatan Gading Cempaka.Awalnya, rumah tersebut adalah milik seorang pedagang Tionghoa yang bernama Lion Bwe Seng yang disewa oleh orang Belanda untuk menempatkan Soekarno selama diasingkan di Bengkulu.Soekarno menempati rumah itu pada 1938-1942. Di rumah ini terdapat barang-barang peninggalan Soekarno. Ada ranjang besi yang pernah dipakai Soekarno dan keluarganya, koleksi buku yang mayoritas berbahasa Belanda serta seragam grup tonil Monte Carlo asuhan Soekarno semasa di Bengkulu. Ada juga foto-foto Soekarno dan keluarganya yang menghiasi hampir seluruh ruangan dan yang tidak kalah menarik adalah sepeda tua yang dipakai Soekarno selama di Bengkulu.

Rumah pengasingan Bung Karno merupakan tempat sejarahnya Soekarno dan banyak peninggalan barang-barang Soekarno, Sehingga banyak wisatawan yang tertarik berkunjung kesana. Untuk itu pihak pengelola perlu untuk selalu mendapatkan informasi yang berasal dari konsumen sebagai masukan bagi penyempurnaan kualitas objek wisata.

\section{LANDASAN TEORI}

Jasa

Jasa atau layanan sering dipandang sebagai suatu fenomena yang rumit. Jasa atau layanan itu sendiri mempunyai banyak arti, mulai dari pelayanan personal (personal service) sampai jasa suatu produk. Sejauh ini, sudah banyak pakar pemasaran yang telah berusaha mendefinisikan pengaturan jasa. Menurut Kotler dalam dan Keller (2009 : 42) Jasa adalah setiap tindakan atau kegiatan yang dapat ditawarkan oleh satu pihak kepada pihak lain, yang pada dasarnya tidak berwujud dan tidak mengakibatkan kepemilikan sesuatu. Produksinya dapat dikaitkan atau tidak dikaitkan pada satu produk fisik.

Jasa menurut Tjiptono (2007: 6) adalah setiap tindakan atau perbuatan yang dapat ditawarkan oleh suatu pihak kepada lain, yang pada dasarnya bersifat intangible (tidak berwujud fisik) dan tidak menghasilkan kepemilikan seseatu. Produk jasa bisa berhubungan dengan produk fisik maupun tidak.

Produksi jasa ini bisa dikaitkan dengan produk fisik maupun tidak. Lima kategori dari penawaran adalah sebagai berikut:

1. Barang berwujud.

2. Barang berwujud disertai jasa pelayanan

3. Kombinasi seimbang.

4. Jasa pelayanan utama disertai barang dan jasa tambahan.

5. Jasa pelayanan saja.

Sebenarnya pembedaan secara tegas antara barang dan jasa seringkali sukar dilakukan. Hal ini dikarenakan pembelian suatu barang seringkali disertai dengan jasa-jasa tertentu dan sebaliknya pembelian suatu jasa seringkali juga melibatkan barang-barang yang melengkapinya.

Karakteristik jasa menurut Kotller dan Keller (2009:227) adalah:

1. Intangibility (tidak berwujud)

2. Inseparability (tidak terpisahkan)

3. Variability (bervariasi)

4. Persihability (tidak tahan lama) 


\section{Pariwisata}

Pengertian pariwisata adalah cara etimologis berasal dari bahasa sansekerta yang terdiri dari dua suku kata yaitu "Pari" yang berarti banyak, berkali-kali, berputar-putar, dan lengkap, dan "Wisata" yang berarti perjalanan atau berpergian. Dengan demikian pariwisata dapat disimpulkan suatu perjalanan yang dilakukan secara berkali-kali atau berputar-putar dari suatu tempat ke tempat yang lain. Menurut definisi yang luas, pariwisata adalah suatu perjalanan dari satu tempat ke tempat yang lain, yang bersifat sementara dan dilakukan perorangan atau kelompok sebagai pencari keseimbangan atau keserasian dan kebahagiaan dengan lingkungan hidup dalam dimensi sosial dan budaya, alam dan ilmu kegiatan kepariwisatawan ada yang disebut subjek wisata orang-orang yang melakukan perjalanan wisata dan objek wisata yang merupakan tujuan wisatawan. Bermacam-macam pendapat para ahli mengenai pengertian pariwisata. Suwartono (1997:14) menyimpulkan "Kepariwisatawan adalah suatu proses kepergian sementara dari seseorang, lebih menuju ke tempat lain diluar tempat tinggalnya".

Obyek wisata merupakan daya tarik utama yang bisa menggerakkan seseorang untuk datang ke suatu lokasi wisata. Tanpa daya tarik, fasilitas dan pelayanan tidak akan diperlukan karena alasan orang mengunjungi suatu lokasi wisata yang pertama dicari adalah daya tariknya bukan fasilitas atau pelayanannya oleh sebab itu, pengaturan dan pemeliharaan terhadap objek wisata merupakan seseatu yang penting, mendahului kepentingan usaha untuk menyediakan fasilitas dan pelayanan wisatanya.

\section{Layanan}

Salah satu cara agar penjualan jasa suatu perusahaaan lebih unggul dbandingkan para pesaingnya adalah dengan memberikan pelayanan yang berkualitas dan bermutu yang memenuhi tingkat kepentingan konsumen. Tingkat kepentingan konsumen terhadap jasa yang akan mereka terima dapat dibentuk berdasarkan pengalaman dan saran yang mereka peroleh. Konsumen memilih pemberi jasa berdasarkan peringkat kepentingan. Dan setelah menikmati jasa tersebut mereka cenderung akan membandingkannya dengan yang mereka harapkan. Barata (2004:23) mengemukakan bahwa: "Pelayanan adalah daya tarik yang besar bagi para pelanggan, sehingga korporat bisnis seringkali menggunakannya sebagai alat promosi untuk menarik minat pelanggan."

Tingkat kualitas layanan tidak dapat dinilai berdasarkan sudut pandang perusahaan tetapi harus dipandang dari sudut pandang pelanggan. Karena itu, dalam merumuskan strategi dan program pelayanan, perusahaan harus berorientasi pada kepentingan pelanggan dengan memperhatikan komponen kualitas pelanggan. Kualitas layanan (service quality) sangat bergantung pada tiga hal, yaitu: sistem, teknologi dan manusia. Faktor manusia memegang kontribusi terbesar sehingga kualitas layanan lebih sulit ditiru dibandingkan dengan kualitas produk dan harga. Kualitas layanan harus dimulai dari kebutuhan pelanggan dan berakhir dengan kepuasan pelanggan serta persepsi terhadap kualitas jasa. Sebagai pihak yang membeli dan mengkonsumsi jasa, pelanggan dan bukan penyedia jasa yang menilai tingkat kualitas jasa sebuah perusahaan.

\section{Kepuasan Wisatawan}

Kepuasan adalah tingkat perasaan seseorang setelah membandingkan kinerja/hasil yang dirasakan dengan harapan. Kepuasan pelanggan merupakan suatu hal yang menjadi harapan perusahaan khususnya. Kepuasan diperoleh apabila kebutuhan dan keinginan pelanggan terpenuhi, sedangkan keinginan dan kebutuhan manusia selalu berubah dan tidak ada batasnya. Dari pengertian tersebut dapat diartikan bahwa kepuasan wisatawan adalah perbandingan antara kinerja produk yang dihasilkan dengan kinerja yang dirasakan oleh wisatawan. Jika berada dibawah harapan, wisatawan tidak puas. Jika kinerja memenuhi harapan, wisatawan puas. Jika kinerja melebihi harapan, wisatawan amat puas atau senang. pengertian secara umum mengenai kepuasan atau ketidak-puasan konsumen merupakan hasil dari adanya perbedaaan-perbedaan antara harapan konsumen dengan kinerja yang dirasakan oleh konsumen tersebut.

Seperti yang dijelaskan oleh Sugiama (2004:15) ada lima hal pokok daerah tujuan wisata yang diminati, yaitu harus memenuhi beberapa kriteria:

1. Rasa Aman adalah perasaan wisatawan atas situasi dan kondisi keamanan selama berwisata, sebagai manifestasi intensitas layanan keamanan wisatawan dari pihak penyedia selama berekreasi di suatu destinasi.

2. Rasa Nyaman adalah Perasaan wisatawan atas kenyamanan lingkungan daerah wisata selama berekreasi, sebagai manifestasi intensitas kualitas pelayanan kenyamanan yang telah diberikan penyedia untuk wisatawan selama berwisata.

3. Kualitas Penyajian Informasi Wisata yaitu Penilaian wisatawan terhadap kualitas pelayanan penyediaaan dalam penyajian informasi wisata kesuatu daerah wisata. 
4. Kelengkapan Fasilitas objek wisata yang berkualitas yaitu Penilaian wisatawan terhadap intensitas usaha penyedia dalam menyediakan peralatan dan perlengkapan fisik rekreasi yang berkualitas di suatu daerah wisata.

5. Tingkat Ketrampilan Komunikasi para petugas yakni Penilaian wisata atas kemampuan para petugas dalam berkomunikasi dengan wisatawan selama berekreasi di suatu daerah wisata.

Menurut Kotler dan Keller (2009:190) wisatawan sendiri yang membentuk pasar wisatawan (tourist market) dan wisatawan organisasional yang membentuk pasar bisnis (business market). Adapun konsep personal tourist dalam definisi perilaku wisatawan dapat lebih dijelaskan bahwa personal wisatawan merupakan individu yang membeli barang dan jasa untuk dirinya sendiri, memenuhi kebutuhan keluarga dan dijadikan hadiah untuk orang lain sehingga personal wisatawan merupakan pengguna terakhir.

\section{Pengaruh Kualitas Objek wisata Terhadap kepuasan Wisatawan}

Banyak peneliti yang sepakat bahwa kepuasan wisatawan merupakan ukuran spesifik untuk setiap transaksi, situasi atau interaksi (encounter) yang bersifat jangka pendek, sedangkan kualitas jasa merupakan sikap yang dibentuk dari evaluasi keseluruhan terhadap kinerja perusahaan dalam jangka panjang.Akan tetapi hubungan antara kedua konsep tersebut kerapkali belum jelas. Sejumlah peneliti melontarkan isu seputar apakah kualitas jasa dan kepuasan pelanggan merupakan konstruk yang sama atau berbeda.

Salah satu kemungkinan yang banyak disepakati adalah kepuasan membantu pelanggan dalam merevisi persepsinya terhadap kualitas jasa dan objek wisata. (Tjiptono dan Chandra, 2005 : 209)

Dari definisi yang telah dikemukakan diatas dapat disimpulkan bahwa hubungan kualitas objek wisata antara kepuasan wisatawan dan kualitas jasa diintegrasikan dengan cara menentukan dua konsep perceived quality, yaitu transaction-sfecific quality dan relationship quality. Perceived transaction sfecific quality diperlakukan sebagai komponen kinerja spesifik pada transaksi tertentu dalam model kepuasan wisatawan kontemporer. Ini menyiratkan bahwa transaction sfecific satisfaction merupakan fungsi dari perceived transaction specific performance quality. Sebaliknya, perceived relationship quality diasumsikan sebagai penilaian atau sikap global berkenaan dengan superioritas jasa.

\section{KERANGKA ANALISIS}

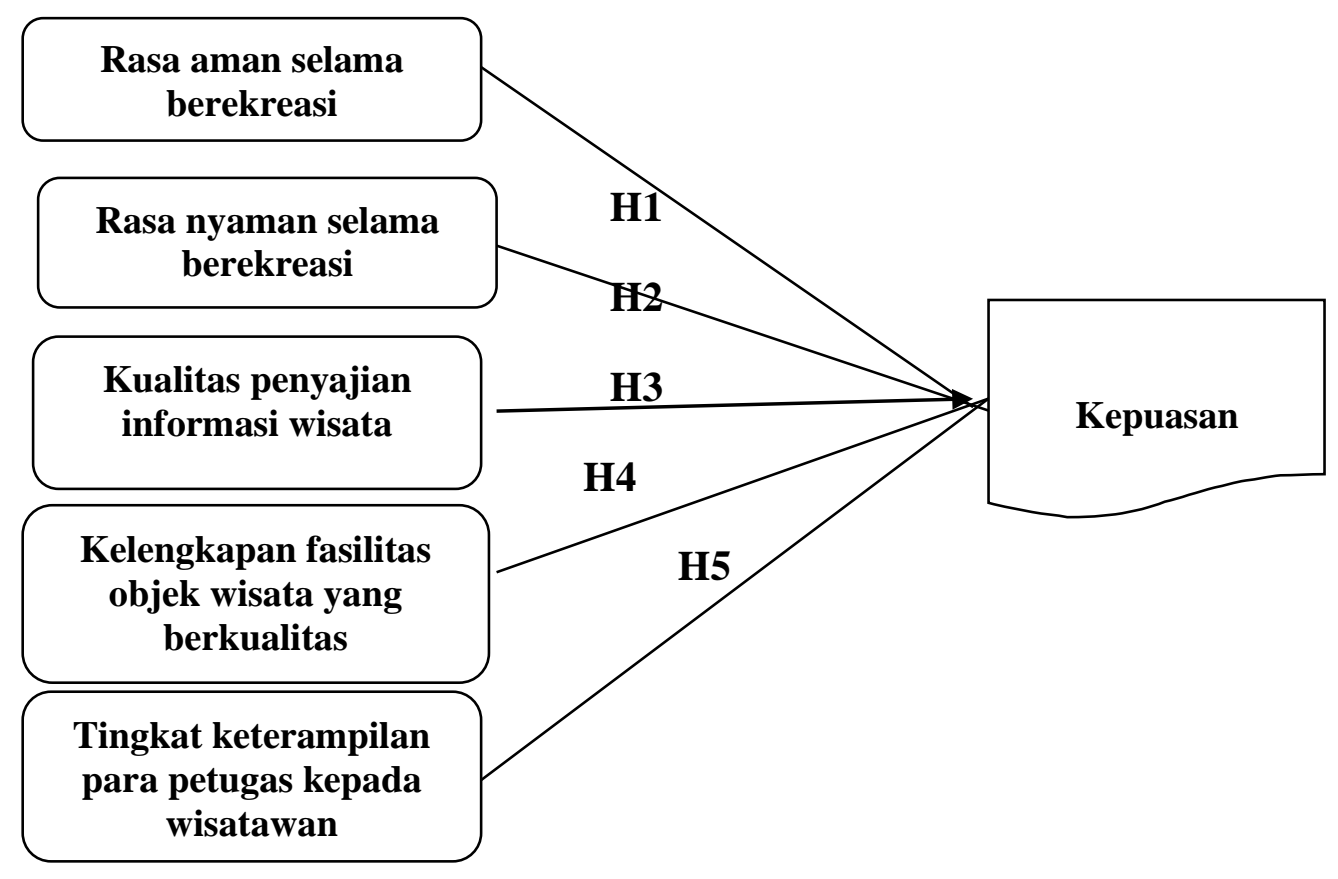

Gambar 1. Kerangka Analisis

\section{METODOLOGI}

Penelitian ini pada intinya merupakan upaya menggali pendapat wisatawan terhadap Kualitas Objek Wisata Sejarah Rumah Pengasingan Bung Karno di Bengkulu. Populasi dalam penelitian ini adalah 
seluruh wisatawan yang berkunjung Ke Rumah Pengasingan Bung Karno Bengkulu. Sampel dari penelitian ini diambil dari seluruh wisatawan yang berkunjung Kerumah Pengasingan Bung Karno pada tahun 2016 sebanyak 250 orang. Pengambilan responden dilakukan dengan teknik accidental sampling, yaitu peneliti memilih siapa saja anggota populasi yang secara kebetulan bertemu dengan peneliti dianggap dapat memberikan informasi yang diperlukan (Sugiyono, 2013:85).

\section{HASIL PENELITIAN DAN PEMBAHASAN}

Responden dalam penelitian ini adalah wisatawan yang berkunjung ke rumah pengasingan Bung Karno. Sampel yang yang diambil sebanyak 72 orang. Berdasarkan hasil penelitian diketahui karakteristik responden meliputi:

\section{Karakteristik Data Responden Berdasarkan Jenis Kelamin}

Berdasarkan jenis kelamin, wisatawan yang berkunjung ke Rumah Pengasingan Bung karno dapat dilihat pada Gambar 2:

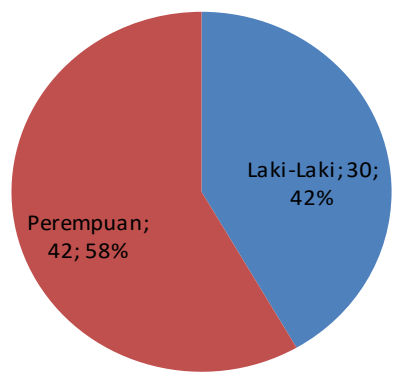

Gambar 2. Responden Berdasarkan Jenis Kelamin

Sumber : Hasil Penelitian (Data Diolah) 2016.

Gambar 2. menunjukkan bahwa responden terbanyak sebagian besar wisatawan Perempuan dengan persentase 58\% dari jumlah keseluruhan responden, sedangkan jumlah wisatawan laki-laki sebanyak 42\%. Kenyataan ini menunjukkan bahwa wisatawan Rumah Pengasingan Bung karno ini kebanyakan berasal dari kaum perempuan.

\section{Karakteristik Data Responden Berdasarkan Usia}

Berdasarkan usia wisatawan yang berkunjung ke Rumah Pengasingan Bung Karno dapat dilihat pada gambar 3 .

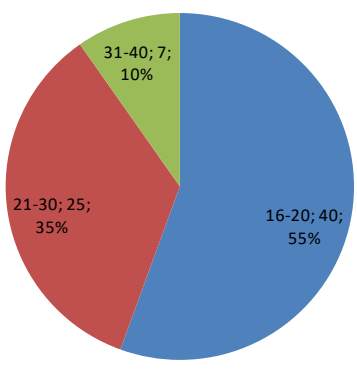

Gambar 3. Responden Berdasarkan Usia

Sumber : Hasil Penelitian (Data Diolah) 2016.

Gambar 3. menunjukkan bahwa hampir dari setengah wisatawan yang berkunjung ke rumah pengasingan Bung karno berusia 16-20 tahun dengan persentase 55\%, sedangkan urutan kedua wisatawan usia 21-30 tahun dengan persentase 35\% dan urutan ketiga wisatawan usia 31-40 tahun dengan persentase 10\%. Hal ini menunjukkan umumnya wisatawan Rumah Pengasingan Bung Karno adalah mereka yang berusia produktif dengan kata lain memiliki pengetahuan wisata dalam menentukan tempat untuk melakukan aktifitas wisata yang sifatnya menarik. Mereka yang termasuk dalam kelompok usia ini berpengaruh 
besar terhadap profitabilitas Rumah Pengasingan Bung Karno ini, sedangkan wisatawan usia 31-40 tahun atau lebih diduga berpengaruh kecil terhadap keputusan purchasing di Rumah Pengasingan Bung Karno ini.

\section{Karakteristik Responden Berdasarkan Pengalaman Berkunjung.}

Berdasarkan pengalaman berkunjung ke wisata Rumah Pengasingan Bung Karno dapat dilihat pada Gambar 4.

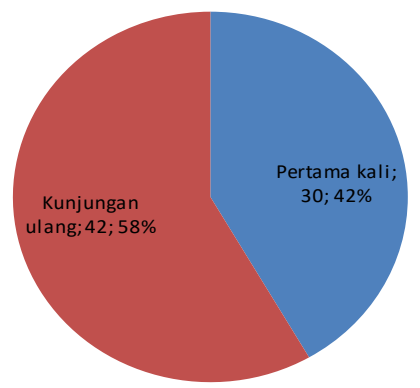

Gambar 4. Responden Berdasarkan Pengalaman Berkunjung

Sumber : Hasil Penelitian (Data Diolah) 2016.

Gambar 4. menunjukkan bahwa responden sebanyak 42 orang dengan persentase 58\% mengaku pernah mengunjungi wisata Rumah Pengasingan Bung Karno sebelumnya Dan ini menjadi mayoritas diantara keseluruhan responden yang di survei. Ini juga dapat membuktikan bahwa wisata Rumah Pengasingan Bung Karno dapat memberikan kepuasan kepada wisatawan sehingga mereka mau berkunjung kembali. Sedangkan yang baru pertama kali berkunjung sebanyak 30 orang dengan persentase $42 \%$ responden.

\section{Tanggapan Responden Terhadap Variabel Yang Diteliti}

Untuk menjelaskan tanggapan responden terhadap variabel penelitian, maka penelitian mengambil ratarata antara 1-5, digunakan untuk mengetahui persepsi wisatawan terhadap variabel penelitian

$$
\text { interval kelas }=\frac{\text { bobot tertinggi-bobot terendah }}{\text { jumlah kelas }}=\frac{5-1}{5}=0,8
$$

Sehingga sebaran kelasnya menjadi:

$$
\begin{array}{ll}
1,00-1,80 & =\text { Sangat tidak puas } \\
1,81-2,60 & =\text { Tidak puas } \\
2,61-3,40 & =\text { Kurang puas } \\
3,41-4,20 & =\text { Puas } \\
4,21-5,00 & =\text { Sangat puas }
\end{array}
$$

Dari pernyataan tersebut akan diambil jumlah rata-rata pada setiap variabel. Nilai rata-rata ini merupakan kepentingan bagi masing-masing variabel yang diteliti. Adapun tanggapan responden terhadap kuesioner yang disebarkan pada tiap variabel yang di teliti sebagai berikut:

\begin{tabular}{|c|c|c|c|c|c|c|c|c|}
\hline \multirow[t]{2}{*}{ No. } & \multirow[t]{2}{*}{ Pernyataan } & \multicolumn{5}{|c|}{ Nilai (Skor) } & \multirow[t]{2}{*}{ Jumlah } & \multirow[t]{2}{*}{ Rata-rata } \\
\hline & & 1 & 2 & 3 & 4 & 5 & & \\
\hline 1 & Pernyataan 1 & 0 & 1 & 6 & 25 & 40 & 320 & 4,44 \\
\hline 2 & Pernyataan 2 & 0 & 1 & 7 & 27 & 37 & 316 & 4,38 \\
\hline 3 & Pernyataan 3 & 0 & 0 & 7 & 27 & 38 & 319 & 4,43 \\
\hline \multicolumn{8}{|c|}{ Rata-rata } & 4,41 \\
\hline
\end{tabular}

1. Tanggapan Responden Terhadap Variabel Rasa Aman

Berdasarkan penyebaran kuesioner yang dilakukan diketahui tanggapan responden terhadap rasa aman, berdasarkan pilihan jawaban sesuai dengan skor yang diberikan seperti pada Tabel 1. Sebagai berikut:

Tabel 1. Tanggapan Responden Terhadap Rasa Aman

Sumber : Hasil Penelitian (Data Diolah) 2016 
Dari penilaian jawaban responden mengenai variabel rasa aman dengan nilai rata-rata 4,41. Menurut sebaran kelasnya yang sudah ditentukan, nilai ini termasuk dalam 4,21-5,00 yang berarti snagat puas. Hal ini dapat disimpulkan bahwa wisatawan sangat puas terhadap rasa aman pada saat berwisata ke Rumah Pengasingan Bung Karno.

2. Tanggapan Responden Terhadap Variabel Rasa Nyaman

Berdasarkan penyebaran kuesioner diketahui tanggapan responden terhadap rasa nyaman berdasarkan pilihan jawaban sesuai dengan skor yang diberikan seperti pada Tabel 2. Sebagai berikut:

Tabel 2. Tanggapan Responden Terhadap Rasa Nyaman

\begin{tabular}{|c|c|c|c|c|c|c|c|c|}
\hline \multirow[t]{2}{*}{ No. } & \multirow[t]{2}{*}{ Pernyataan } & \multicolumn{5}{|c|}{ Nilai (Skor) } & \multirow[t]{2}{*}{ Jumlah } & \multirow[t]{2}{*}{ Rata-rata } \\
\hline & & 1 & 2 & 3 & 4 & 5 & & \\
\hline 1 & Pernyataan 1 & 0 & 0 & 7 & 30 & 35 & 316 & 4,30 \\
\hline 2 & Pernyataan 2 & 0 & 0 & 6 & 30 & 36 & 318 & 4,41 \\
\hline 3 & Pernyataan 3 & 0 & 0 & 9 & 27 & 36 & 315 & 4,30 \\
\hline \multicolumn{8}{|c|}{ Rata-rata } & 4,33 \\
\hline
\end{tabular}

Sumber : Hasil Penelitian (Data Diolah) 2016.

Dari penilaian jawaban responden terhadap variabel rasa nyaman diperoleh nilai rata-rata sebesar 4,33. Menurut sebaran kelasnya yang telah ditentukan, nilai ini masuk dalam sebaran antara 4,21-5,00 yang berarti sangat puas. Hal ini dapat disimpulkan bahwa wisatawan sangat puas akan rasa nyaman saat berada di Rumah Pengasingan Bung Karno.

3. Tanggapan Responden Terhadap Variabel Kualitas Penyajian Informasi Berdasarkan penyebaran kuesioner diketahui tanggapan responden terhadap kualitas penyajian informasi, berdasarkan pilihan jawaban sesuai dengan skor yang diberikan seperti pada Tabel 3 . Sebagai berikut:

Tabel 3. Tanggapan Responden Terhadap Kualitas Penyajian Informasi

\begin{tabular}{|c|c|c|c|c|c|c|c|c|}
\hline \multirow[t]{2}{*}{ No. } & \multirow[t]{2}{*}{ Pernyataan } & \multicolumn{5}{|c|}{ Nilai (skor) } & \multirow[t]{2}{*}{ Jumlah } & \multirow{2}{*}{ Rata-rata } \\
\hline & & 1 & 2 & 3 & 4 & 5 & & \\
\hline 1 & Pernyataan 1 & 0 & 1 & 13 & 29 & 29 & 302 & 4,19 \\
\hline 2 & Pernyataan 2 & 0 & 1 & 11 & 28 & 32 & 307 & 4,26 \\
\hline 3 & Pernyataan 3 & 0 & 0 & 1 & 37 & 34 & 321 & 4,45 \\
\hline \multicolumn{8}{|c|}{ Rata-rata } & 4,30 \\
\hline
\end{tabular}

Sumber : Hasil Penelitian (Data Diolah) 2016

Dari penilaian jawaban responden terhadap variabel kualitas penyajian informasi diperoleh nilai ratarata sebesar 4,30. Menurut sebaran kelasnya yang sudah ditentukan,nilai ini masuk dalam sebaran antara 4,21-5,00 yang berarti sangat puas. Hal ini menggambarkan kualitas penyajian informasi Rumah Pengasingan Bung Karno sudah baik, sehingga wisatawan sangat puas saat berwisata di Rumah Pengasingan Bung Karno.

4. Tanggapan Responden Terhadap Variabel Kelengkapan Fasilitas

Berdasarkan penyebaran kuesioner diketahui tanggapan responden terhadap kelengkapan fasilitas berdasarkan pilihan jawaban sesuai dengan skor yang diberikan seperti pada Tabel 4. Sebagai berikut:

Tabel 4. Tanggapan Responden Terhadap Kelengkapan Fasilitas

\begin{tabular}{|c|c|c|c|c|c|c|c|c|}
\hline \multirow[t]{2}{*}{ No. } & \multirow[t]{2}{*}{ Pernyataan } & \multicolumn{5}{|c|}{ Nilai (Skor) } & \multirow[t]{2}{*}{ Jumlah } & \multirow[t]{2}{*}{ Rata-rata } \\
\hline & & 1 & 2 & 3 & $\frac{4}{4}$ & 5 & & \\
\hline 1 & Pernyataan 1 & 0 & 0 & 2 & 32 & 38 & 324 & 4,50 \\
\hline 2 & Pernyataan 2 & 0 & 0 & 0 & 43 & 29 & 317 & 4,40 \\
\hline 3 & Pernyataan 3 & 0 & 0 & 3 & 31 & 38 & 323 & 4,48 \\
\hline & & & & & & & & 4,46 \\
\hline
\end{tabular}

Sumber : Hasil Penelitian (Data Diolah) 2016

Dari penilaian jawaban responden mengenai variabel kelengkapan fasilitas diperoleh nilai rata-rata sebesar 4,46. Menurut sebaran kelasnya yang sudah ditentukan, nilai ini masuk dalam sebaran antara 
4,21-5,00 yang berarti sangat puas. Hal ini dapat disimpulkan bahwa wisatawan sangat puas akan kelengakapan fasilitas yang diberikan Rumah Pengasingan Bung Karno.

5 Tanggapan Responden Terhadap Variabel Pelayanan Para Petugas

Berdasarkan penyebaran kuesioner diketahui tanggapan responden terhadap pelayanan para petugas berdasarkan pilihan jawaban sesuai dengan skor yang diberikan seperti pada tabel 5. Sebagai berikut:

Tabel 5. Tanggapan Responden Terhadap Pelayanan Para Petugas

\begin{tabular}{|c|c|c|c|c|c|c|c|c|}
\hline \multirow[t]{2}{*}{ No. } & \multirow[t]{2}{*}{ Pernyataan } & \multicolumn{5}{|c|}{ Nilai (Skor) } & \multirow[t]{2}{*}{ Jumlah } & \multirow[t]{2}{*}{ Rata-rata } \\
\hline & & 1 & 2 & 3 & 4 & 5 & & \\
\hline 1 & Pernyataan 1 & 0 & 0 & 0 & 34 & 38 & 326 & 4,52 \\
\hline 2 & Pernyataan 2 & 0 & 0 & 1 & 31 & 40 & 327 & 4,54 \\
\hline 3 & Pernyataan 3 & 0 & 0 & 5 & 32 & 35 & 318 & 4,41 \\
\hline \multicolumn{8}{|c|}{ Rata-rata } & 4,49 \\
\hline
\end{tabular}

Sumber : Hasil Penelitian (Data Diolah) 2016

Dari penilaian jawaban responden mengenai variabel pelayanan para petugas diperoleh nilai rata-rata sebesar 4,49. Menurut sebaran kelasnya yang sudah ditentukan, nilai ini masuk dalam sebaran antara 4,21-5,00 yang berarti sangat puas. Hal ini dapat disimpulkan bahwa wisatawan sangat puas akan pelayanan para petugas Rumah Pengasingan Bung Karno selama berwisata.

6. Tanggapan Responden Terhadap Variabel Kepuasan Wisatawan.

Berdasarkan penyebaran kuesioner diketahui tanggapan responden terhadap kepuasan wisatawan berdasarkan pilihan jawaban sesuai dengan skor yang diberikan seperti pada Tabel 6. Sebagai berikut:

Tabel 6. Tanggapan Responden Terhadap Kepuasan Wisatawan

\begin{tabular}{|l|l|l|l|l|l|l|l|l|l|}
\hline \multirow{2}{*}{ No. } & Pernyataan & \multicolumn{7}{|c|}{ Jilai (Skor) } & Rata-rata \\
\cline { 3 - 7 } & & 1 & 2 & 3 & 4 & 5 & & \\
\hline 1 & Pernyataan 1 & 0 & 0 & 1 & 33 & 38 & 325 & 4,51 \\
\hline 2 & Pernyataan 2 & 0 & 0 & 2 & 32 & 38 & 324 & 4,50 \\
\hline 3 & Pernyataan 3 & 0 & 0 & 4 & 34 & 34 & 318 & 4,41 \\
\hline \multicolumn{8}{|c|}{ Rata-rata } \\
\hline
\end{tabular}

Sumber: Hasil Penelitian (Data Diolah) 2016

Dari penilaian jawaban responden mengenai variabel kepuasan wisatawan diperoleh nilai rata-rata sebesar 4,47. Menurut sebaran kelasnya yang sudah ditentukan, nilai ini masuk dalam sebaran antara 4,21-5,00 yang berarti sangat puas. Hal ini dapat disimpulkan bahwa wisatawan telah mencapai hasil yang dirasakan sesuai dengan harapan yaitu sangat puas saat berada di Rumah Pengasingan Bung Karno dan wisatawan pun akan datang berkunjung lagi.

\section{Pembahasan}

Dari hasil penelitian terhadap Kualitas Objek Wisata Sejarah Dan Pengaruhnya Terhadap Kepuasan Wisatawan Berkunjung Ke Kota Bengkulu yang dinilai dari indikator rasa aman, rasa nyaman, kualitas penyajian informasi, kelengkapan fasilitas, dan pelayanan para petugas, maka penulis menuangkan hasil analisis kuantitatif dalam penelitian ini dengan jumlah sampel 72 responden adalah sebagai berikut : 
TABEL 7. COEFFICIENTS ${ }^{a}$

\begin{tabular}{|c|c|c|c|c|c|c|c|c|c|c|}
\hline \multirow[b]{2}{*}{ Model } & \multicolumn{2}{|c|}{$\begin{array}{l}\text { Unstandardized } \\
\text { Coefficients }\end{array}$} & \multirow{2}{*}{$\begin{array}{c}\text { Standardized } \\
\text { Coefficients } \\
\text { Beta }\end{array}$} & \multirow[b]{2}{*}{$t$} & \multirow[b]{2}{*}{ Sig. } & \multicolumn{3}{|c|}{ Correlations } & \multicolumn{2}{|c|}{$\begin{array}{l}\text { Collinearity } \\
\text { Statistics }\end{array}$} \\
\hline & $B$ & \begin{tabular}{|l} 
Std. \\
Error
\end{tabular} & & & & $\begin{array}{l}\text { Zero- } \\
\text { order }\end{array}$ & Partial & Part & Tolerance & VIF \\
\hline (Constant) & 4.314 & 1.180 & & 3.654 & .001 & & & & & \\
\hline Rasa Aman & 327 & 101 & 460 & 3.242 & 002 & 477 & 371 & 256 & 310 & 3.222 \\
\hline Rasa Nyaman & -.127 & .092 & -.176 & -1.371 & 175 & 301 & -.166 & -.108 & 378 & 2.649 \\
\hline $\begin{array}{l}\text { Kualitas Penyajian } \\
\text { Informasi }\end{array}$ & .201 & 096 & -.248 & -2.091 & 040 & 216 & -.249 & -.165 & 445 & 2.247 \\
\hline $\begin{array}{l}\text { Kelengkapan } \\
\text { Fasilitas }\end{array}$ & 272 & .091 & 304 & 2.992 & 004 & 574 & 346 & 237 & 607 & 1.648 \\
\hline petugas & 400 & .091 & 441 & 4.390 & 000 & 682 & 475 & 347 & 620 & 1.613 \\
\hline
\end{tabular}

Sumber : Hasil Penelitian (Data Diolah) 2016

TABEL 8. MODEL SUMMARYb

\begin{tabular}{|c|c|c|c|c|c|}
\hline Model & $\mathrm{R}$ & $\mathrm{R}$ Square & Adjusted R Square & Std. Error of the Estimate & Durbin-Watson \\
\hline 1 & $.767 \mathrm{a}$ & .588 & .556 & .805 & 1.778 \\
\hline
\end{tabular}

TABEL 9. ANOVA ${ }^{a}$

\begin{tabular}{|c|c|c|c|c|c|}
\hline Model & Sum of Squares & Df & Mean Square & F & Sig. \\
\hline $\begin{array}{ll}1 & \text { Regression } \\
& \text { Residual } \\
& \text { Total }\end{array}$ & $\begin{array}{l}60.913 \\
42.739 \\
103.653\end{array}$ & $\begin{array}{l}5 \\
66 \\
71\end{array}$ & $\begin{array}{l}12.183 \\
648\end{array}$ & 18.813 & $.000^{\mathrm{b}}$ \\
\hline
\end{tabular}

\section{Uji Validitas}

Uji validitas digunakan untuk mengukur sah atau valid tidaknya suatu data kuesioner, data kuesioner dikatakan valid apabila $r$ hitung lebih besar dari $r$ tabel dengan taraf signifikan 5\%. Dengan menggunakan pengolahan data SPSS 23, adapun hasil penelitian dari pernyataan yang diberikan kepada responden dapat dilihat pada Tabel 10. Sebagai berikut :

Tabel 10. Hasil Pengujian Validitas

\begin{tabular}{|c|c|c|c|c|}
\hline Variabel & Kode Item Pernyataan & r hitung & $r$ tabel & Keterangan \\
\hline \multirow{3}{*}{ Rasa aman } & X1. P1 & 0,652 & 0,227 & Valid \\
\hline & X1. P2 & 0,678 & 0,227 & Valid \\
\hline & X1. P3 & 0,699 & 0,227 & Valid \\
\hline \multirow[t]{3}{*}{ Rasa nyaman } & $\mathrm{X} 2 . \mathrm{P} 1$ & 0,638 & 0,227 & Valid \\
\hline & $\mathrm{X} 2 . \mathrm{P} 2$ & 0,663 & 0,227 & Valid \\
\hline & $\mathrm{X} 2 . \mathrm{P} 3$ & 0,579 & 0,227 & Valid \\
\hline \multirow[t]{3}{*}{ Kualitas penyajian informasi } & X3. P1 & 0,494 & 0,227 & Valid \\
\hline & X3. P2 & 0,453 & 0,227 & Valid \\
\hline & X3. P3 & 0,425 & 0,227 & Valid \\
\hline \multirow[t]{3}{*}{ Kelengkapan fasilitas } & X4. P1 & 0,546 & 0,227 & Valid \\
\hline & $\mathrm{X} 4 . \mathrm{P} 2$ & 0,575 & 0,227 & Valid \\
\hline & X4. P3 & 0,550 & 0,227 & Valid \\
\hline \multirow[t]{3}{*}{ Pelayanan para petugas } & X5. P1 & 0,463 & 0,227 & Valid \\
\hline & X5. P2 & 0,514 & 0,227 & Valid \\
\hline & X5. P3 & 0,513 & 0,227 & Valid \\
\hline \multirow[t]{3}{*}{ Kepuasan wisatawan } & Y.P1 & 0,390 & 0,227 & Valid \\
\hline & Y. P2 & 0,407 & 0,227 & Valid \\
\hline & Y. P3 & 0,422 & 0,227 & Valid \\
\hline
\end{tabular}

Sumber : Hasil Penelitian (Data Diolah) 2016

Berdasarkan Tabel 10. hasil olahan data mengenai pengujian validitas, menunjukkan bahwa untuk variabel rasa aman dengan 3 item pernyataan, variabel rasa nyaman dengan 3 item pernyataan, variabel 
kualitas penyajian informasi dengan 3 item pernyataan, kelengkapan fasilitas dengan 3 item pernyataan, pelayanan para petugas dengan 3 item pernyataan dan kepuasan wisatawan dengan 3 item pernyataan maka dapat disimpulkan bahwa 18 item pernyataan sudah valid karena memiliki nilai korelasi $\mathrm{r}$ hitung di atas dari $r$ tabel $0,227$.

\section{Uji Reliabilitas}

Digunakan untuk mengukur suatu kuesioner yang merupakan indikator dari variabel. Suatu data dikatakan reliabel apabila nilai cronbach alpha diatas 0,6 . Hasil penelitian dari pernyataan yang diberikan kepada responden dapat dilihat pada Tabel XIII. berikut :

\section{Tabel 11. Reliability statistics}

\begin{tabular}{|c|c|}
\hline Cronbach's Alpha & $\mathrm{N}$ of Items \\
\hline 895 & 18 \\
\hline
\end{tabular}

Sumber : Hasil Penelitian (Data Diolah) 2016.

Berdasarkan Tabel 11. hasil olahan data mengenai pengujian reliabilitas, menunjukkan bahwa variabel rasa aman, rasa nyaman, kualitas penyajian informasi, kelengkapan fasilitas, pelayanan para petugas dan kepuasan wisatawan memiliki nilai cronbach's alpha diatas 0,60 yaitu 0,895 artinya kuesioner yang kita buat sudah reliabel karena lebih besar dari 0,60.

\section{Uji Asumsi Klasik}

- Uji Normalitas

Hasil perhitungan normalitas data dapat dilihat pada Gambar 5. Sebagai berikut:

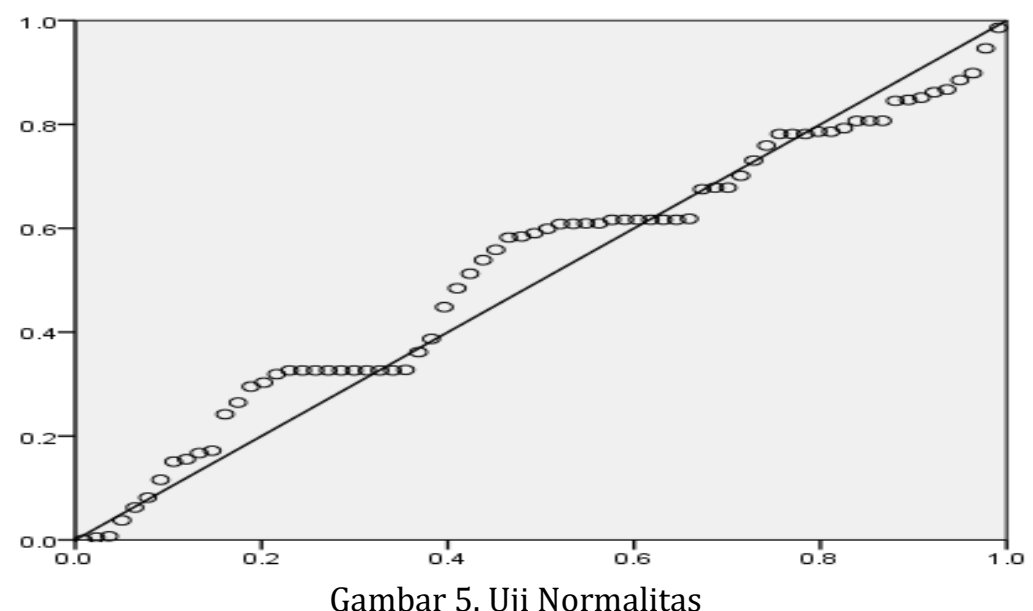

Sumber: Hasil Penelitian (Data Diolah) 2016

Dari hasil output pada Gambar 5. menunjukkan penyebaran plot berada disekitar dan sepanjang garis. Dengan demikian bahwa data-data pada variabel penelitian berdistribusi normal.

- Uji Multikolinieritas

Hasil perhitungan data multikolinieritas dapat dilihat pada Tabel 7. Berdasarkan Tabel 7. hasil olahan data mengenai pengujian multikolinearitas terdapat pada kolom tolerance dengan nilai 0,310 dan VIF 3,222 pada variabel rasa aman, nilai tolerance 0,378 dan VIF 2,649 pada variabel rasa nyaman, nilai tolerance 0,445 dan VIF 2,247 pada variabel kualitas penyajian informasi, nilai tolerance 0,607 dan VIF 1,648 pada variabel kelengkapan fasilitas dan nilai tolerance 0,620 dan VIF 1,613 pada variabel pelayanan para petugas. Karena tolerance kelima variabel tersebut lebih besar dari 0,1 dengan nilai VIF kurang dari 10, maka persamaan regresi yang diperoleh tidak mengandung multikolinieritas.

- Uji Heteroskedastisitas

Hasil uji heteroskedastisitas dapat dilihat pada Gambar 6. 


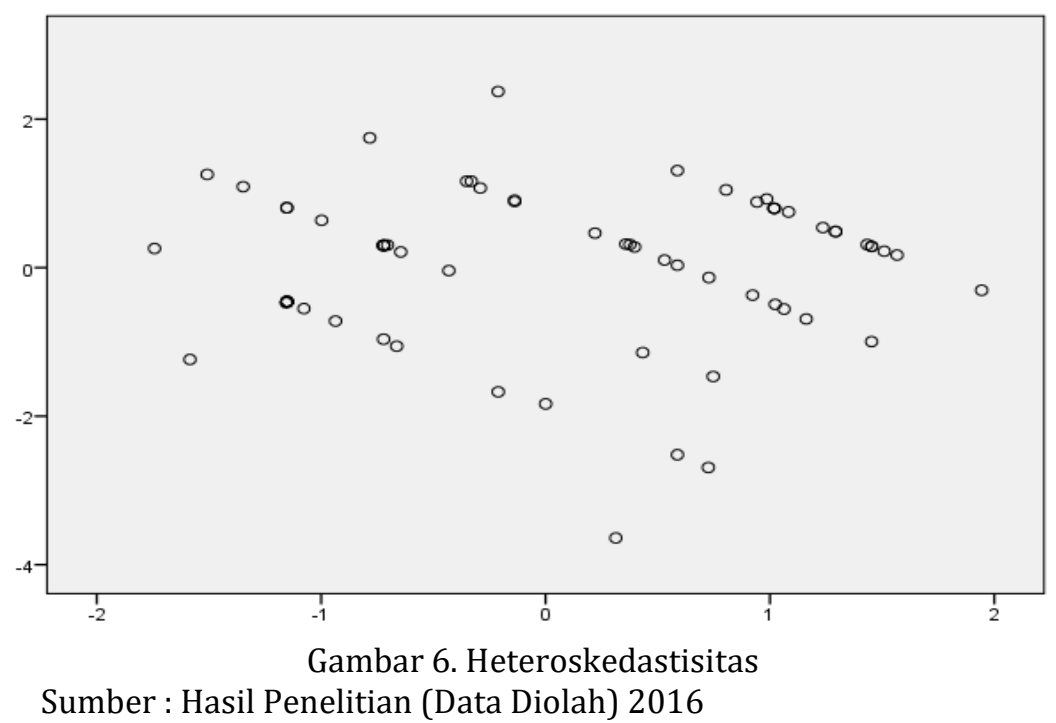

Berdasarkan hasil analisis diperoleh scatter plot yang tidak membentuk pola tertentu, maka model regresi tidak memiliki gejala heteroskedastisitas.

\section{Persaman Regresi Linear Berganda}

Berdasarkan hasil perhitungan regresi dengan bantuan SPSS 23 pada Tabel 7. terletak di Kolom B, maka didapat persamaan regresi berganda sebagai berikut:

\section{$Y=4,314+0,327 \times 1+-0,127 \times 2+-0,201 X 3+0,272 \times 4+0,400 \times 5$}

Dari persamaan regresi tersebut dapat diartikan bahwa:

> Nilai konstanta 4,314 menunjukkan nilai yang positif, dapat diartikan bahwa jika tidak dipengaruhi oleh variabel independen yang terdiri dari rasa aman $\left(\mathrm{X}_{1}\right)$, rasa nyaman $\left(\mathrm{X}_{2}\right)$, kualitas penyajian informasi $\left(\mathrm{X}_{3}\right)$, kelengkapan fasilitas $\left(\mathrm{X}_{4}\right)$ dan pelayanan para petugas $\left(\mathrm{X}_{5}\right)$, maka kepuasan wisatawan tidak mengalami perubahan.

> Nilai koefisien regresi untuk variabel rasa aman adalah 0,327 dapat diartikan bahwa jika variabel rasa aman ditingkatkan sedangkan variabel lain tetap, maka kepuasan wisatawan akan mengalami peningkatan dengan nilai sebesar 0,327 .

> Nilai koefisien regresi untuk variabel rasa nyaman adalah -0,127 dapat diartikan bahwa jika variabel rasa nyaman ditingkatkan sedangkan variabel lain tetap, maka kepuasan wisatawan akan mengalami penurunan dengan nilai sebesar $-0,127$.

> Nilai koefisien regresi untuk variabel kualitas penyajian informasi adalah - 0,201 dapat diartikan bahwa jika variabel kualitas penyajian informasi ditingkatkan sedangkan variabel lain tetap, maka kepuasan wisatawan akan mengalami penurunan dengan nilai sebesar - 0,201.

$>\quad$ Nilai koefisien regresi untuk variabel kelengkapan fasilitas adalah 0,272 dapat diartikan bahwa jika variabel kelengkapan fasilitas ditingkatkan sedangkan variabel lain tetap, maka kepuasan wisatawan akan mengalami peningkatan dengan nilai sebesar 0,272.

$>\quad$ Nilai koefisien regresi untuk variabel pelayanan para petugas adalah 0,400 dapat diartikan bahwa jika variabel pelayanan para petugas ditingkatkan sedangkan variabel lain tetap, maka kepuasan wisatawan akan mengalami peningkatan dengan nilai sebesar 0,400 .

\section{Korelasi Berganda}

Berdasarkan hasil perhitungan koefisien korelasi linear berganda pada Tabel 8, diperoleh nilai $R=0,767$. Hal ini menunjukkan pada pedoman interperstasi koefisien korelasi dimana interval koefisiennya 0,600,799 yang memiliki tingkat hubungan yang kuat artinya variabel bebas yang terdiri dari rasa aman ( $\left.\mathrm{X}_{1}\right)$, rasa nyaman $\left(\mathrm{X}_{2}\right)$, kualitas penyajian informasi $\left(\mathrm{X}_{3}\right)$, kelengkapan fasilitas $\left(\mathrm{X}_{4}\right)$, pelayanan para petugas $\left(\mathrm{X}_{5}\right)$ mempunyai hubungan yang kuat tehadap variabel terikat yaitu kepuasan wisatawan $(\mathrm{Y})$.

\section{Koefisien Determinasi Berganda $\left(\mathbf{R}^{2}\right)$}

Berdasarkan hasil perhitungan koefisien determinasi $\left(\mathrm{R}^{2}\right)$ dapat dilihat pada tabel 8. diperoleh nilai $R$ Square $=0,588$. Hal ini menunjukkan bahwa variabel bebas yang terdiri dari rasa aman $\left(\mathrm{X}_{1}\right)$, rasa nyaman $\left(X_{2}\right)$, kualitas penyajian informasi $\left(X_{3}\right)$, kelengkapan fasilitas $\left(X_{4}\right)$, pelayanan para petugas $\left(X_{5}\right)$ secara 
bersama-sama mampu menjelaskan variabel terikat kepuasan wisatawan $\left(\mathrm{X}_{5}\right)$ sebesar 58,8 \%, sedangkan sisanya $100 \%-58,8 \%=41,2 \%$ dipengaruhi oleh faktor lain yang tidak diteliti.

\section{Uji t (Uji Parsial)}

Dalam penelitian ini, uji $\mathrm{t}$ digunakan untuk menguji apakah terdapat pengaruh yang signifikan antara variabel bebas terhadap variabel terikat secara terpisah. Dari hasil analisis uji t dapat dijelaskan sebagai berikut :

a. Nilai thitung untuk variabel rasa aman $\left(\mathrm{X}_{1}\right)$ adalah 3,242 dan tabel diperoleh 1,668 dengan taraf signifikansi 0,05 . Karena $t_{\text {hitung }}>t_{\text {tabel }}(3,242>1,668)$ ini berarti variabel rasa aman mempunyai pengaruh yang signifikan terhadap kepuasan wisatawan (Y).

b. Nilai thitung untuk variabel rasa nyaman $\left(\mathrm{X}_{2}\right)$ adalah $-1,371$ dan tabel diperoleh 1,668 dengan taraf signifikansi 0,05 . Karena $t_{\text {hitung }}<t_{\text {tabel }}(-1,371<1,668)$ ini berarti variabel rasa nyaman $\left(\mathrm{X}_{2}\right)$ tidak mempunyai pengaruh yang signifikan terhadap kepuasan wisatawan $(\mathrm{Y})$.

c. Nilai thitung untuk variabel kualitas penyajian informasi (X3) adalah -2,091 dan ttabel diperoleh 1,668 dengan taraf signifikansi 0,05 . Karena thitung $<$ tabel $(-2,091<1,668)$ ini berarti variabel kualitas penyajian informasi $\left(\mathrm{X}_{3}\right)$ tidak mempunyai pengaruh yang signifikan terhadap kepuasan wisatawan (Y).

d. Nilai thitung untuk variabel kelengkapan fasilitas $\left(\mathrm{X}_{4}\right)$ adalah 2,992 dan tabel diperoleh 1,668 dengan taraf signifikansi 0,05. Karena thitung $>$ ttabel $(2,992>1,668)$ ini berarti variabel kelengkapan fasilitas $\left(\mathrm{X}_{4}\right)$ mempunyai pengaruh yang signifikan terhadap kepuasan wisatawan $(\mathrm{Y})$.

e. Nilai thitung untuk variabel pelayanan para petugas ( $\mathrm{X}_{5}$ ) adalah 1,228 dan tabel diperoleh 1,690 dengan taraf signifikansi 0,05 . Karena thitung $>$ ttabel $(4,390>1,668)$ ini berarti menunjukkan bahwa variabel pelayanan para petugas $\left(\mathrm{X}_{5}\right)$ mempunyai pengaruh yang signifikan terhadap kepuasan wisatawan (Y).

\section{Uji F (Uji Simultan)}

Uji F digunakan untuk mengetahui pengaruh variabel bebas secara bersama-sama terhadap variabel terikat. Kriteria pengujian uji $\mathrm{F}$ sebagai berikut :

$>\quad$ Jika Fhitung $<$ Ftabel maka Ho diterima dan Ha ditolak berarti secara bersama-sama tidak ada pengaruhnya.

$>\quad$ Jika $F_{\text {hitung }}>\mathrm{F}_{\text {tabel }}$ maka Ho ditolak dan Ha diterima berarti secara bersama-sama ada pengaruhnya.

$>$ Menentukan Ftabel :

Dengan menggunakan tingkat keyakinan keyakinan 95\%, a = 5\%, df 1 atau 6-1=5 dan df 2 (n-k-1) atau $72-5-1=66$.

Dari hasil pengolahan data, diperoleh nilai $F_{h i t u n g}$ sebesar 18,813 sedangkan $F_{\text {tabel }}$ dengan a $=0,05$ adalah sebesar 2,35. Karena nilai $F_{\text {hitung }}>F_{\text {tabel }}(18,813>2,35)$ artinya variabel bebas yang terdiri dari rasa aman $\left(\mathrm{X}_{1}\right)$, rasa nyaman $\left(\mathrm{X}_{2}\right)$, kualitas penyajian informasi $\left(\mathrm{X}_{3}\right)$, kelengkapan fasilitas $\left(\mathrm{X}_{4}\right)$ dan pelayanan para petugas $\left(\mathrm{X}_{5}\right)$ secara bersama-sama berpengaruh signifikan terhadap kepuasan wisatawan $(\mathrm{Y})$

\section{KESIMPULAN}

1. Persamaan Regresi Linear Berganda

$\mathrm{Y}=4,314+0,327 \mathrm{X} 1+-0,127 \mathrm{X} 2+-0,201 \mathrm{X} 3+0,272 \mathrm{X} 4+0,400 \mathrm{X} 5$

Nilai Konstanta 4,314 menunjukkan nilai yang positif dan mempunyai makna jika tidak dipengaruhi oleh variabel independen yang terdiri dari rasa aman $\left(\mathrm{X}_{1}\right)$ sebesar 0,327 , rasa nyaman $\left(\mathrm{X}_{2}\right)$ sebesar 0,127 , kualitas penyajian informasi $\left(X_{3}\right)$ sebesar $-0,201$, kelengkapan fasilitas $\left(X_{4}\right)$ sebesar 0,272 , pelayanan para petugas $\left(\mathrm{X}_{5}\right)$ sebesar 0,400 , maka kepuasan wisatawan tidak mengalami perubahan.

2. Pada korelasi berganda nilai $R$ sebesar 0,767 hal ini menunjukkan bahwa hubungan antara variabel bebas rasa aman $\left(\mathrm{X}_{1}\right)$, rasa nyaman $\left(\mathrm{X}_{2}\right)$, kualitas penyajian informasi $\left(\mathrm{X}_{3}\right)$, kelengkapan fasilitas $\left(\mathrm{X}_{4}\right)$, pelayanan para petugas $\left(\mathrm{X}_{5}\right)$ terhadap variabel terikat kepuasan wisatawan $(\mathrm{Y})$ memiliki tingkat hubungan yang kuat.

3. Pada koefisien determinasi $\left(R^{2}\right)$ diperoleh nilai 0,588 yang menunjukkan bahwa variabel bebas yaitu rasa aman $\left(X_{1}\right)$, rasa nyaman $\left(X_{2}\right)$, kualitas penyajian informasi $\left(X_{3}\right)$, kelengkapan fasilitas $\left(X_{4}\right)$, pelayanan para petugas $\left(\mathrm{X}_{5}\right)$ secara bersama-sama mampu menjelaskan variabel terikat kepuasan wisatawan ( $\mathrm{Y}$ ) sebesar 58,8\%.

4. Nilai thitung yang diperoleh dari variabel bebas yaitu 3,242 pada rasa aman $\left(\mathrm{X}_{1}\right),-1,371$ pada rasa nyaman $\left(\mathrm{X}_{2}\right),-2,091$ pada kualitas penyajian informasi $\left(\mathrm{X}_{3}\right), 2,992$ pada kelengkapan fasilitas $\left(\mathrm{X}_{4}\right)$, 4,390 pada pelayanan para petugas ( $\mathrm{X}_{5}$ ). Dari nilai tersebut dapat disimpulkan bahwa variabel rasa 
aman, kelengkapan fasilitas dan pelayanan para petugas berpengaruh secara parsial terhadap kepuasan wisatawan (Y), karena nilai thitung $>t_{\text {tabel }}$ dengan tingkat keyakinan $a=0,05$ dengan nilai sebesar 1,668. Sedangkan rasa nyaman dan kualitas penyajian informasi tidak berpengaruh secara parsial terhadap kepuasan wisatawan karna thitung $<t_{\text {tabel. }}$.

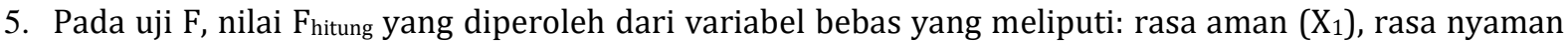
$\left(\mathrm{X}_{2}\right)$, kualitas penyajian informasi $\left(\mathrm{X}_{3}\right)$, kelengkapan fasilitas $\left(\mathrm{X}_{4}\right)$ dan pelayanan para petugas $\left(\mathrm{X}_{5}\right)$ yaitu sebesar 18,813 sedangkan $F_{\text {tabel }}$ dengan tingkat keyakinan a = 0,05 adalah sebesar 2,35 berarti secara bersama-sama berpengaruh terhadap variabel terikat yaitu kepuasan wisatawan (Y). Hal ini menunjukkan bahwa nilai $F_{\text {hitung }}>\mathrm{F}_{\text {tabel }}(18,813>2,35)$ maka Ho ditolak dan Ha diterima.

\section{Saran}

1. Pengelola objek wisata rumah pengasingan Bung Karno sebaiknya harus meningkatkan rasa nyaman dan kualitas penyajian informasi karena variabel tersebut merupakan nilai yang paling rendah terhadap kepuasan wisatawan, oleh karena itu objek wisata rumah pengasingan Bung Karno harus lebih memperhatikan dan merawat kebersihan kelestarian lingkungan demi kenyamanan wisatawan serta lebih cepat tanggap dalam penyajian informasi. Dengan adanya kenyamanan dan bertambahnya pengetahuan informasi saat berwisata, maka wisatawan pun akan merasa puas.

2. Untuk yang akan datang penelitian ini diharapkan dapat digunakan sebagai bahan pertimbangan dengan menambah variabel-variabel lain agar terciptanya kepuasan wisatawan.

\section{DAFTAR PUSTAKA}

Ardhana Duky, 2014 ,Pengaruh Kualitas Objek Wisata Sumatra Barat Terhadap Kepuasan wisatawan. Jurnal. Universitas Andalas.

Barata, Atep Adya. 2004. Dasar-dasar Pelayanan Prima (cetakan kedua). Elek Media Komputindo: Jakarta. Carl Mc. Daniel and Roger Gates,2001, Riset Pemasaran Kontemporer Salemba Empat, Jakarta.

Ghozali, Imam. 2005. Aplikasi analisis Multivariase Dengan Program SPSS. Semarang : Program Magister Manajemen UNDIP.

Kotler Philip \& Kevin Lane Keller,2009,Manajemen Pemasaran,Edisi 13 Jilid 1, Jakarta.

Sari. W, Irine Diana. 2010. Metode Pemasaran. Nuha Medika. Yogyakarta.

Sugiama, Aceng Gema, 2004. Dampak Pengembangan Usaha Kepariwisataan terhadap kepuasan pengalaman berwisata, Disertasi ITB, Bandung.

Sugiyono, 2013. Metode Penelitian Pendidikan: pendekatan kuantitatif dan kualitatif. Bandung: Alfabeta.

Sulaiman, Wahid. 2004. Analisis Regresi Menggunakan SPSS Contoh Kasus \& Pemecahannya. Yogyakarta: Andi.

Sunarto, 2003, Manajemen Pemasaran, Penerbit : Amus, Yogyakarta.

Suwartono Gamal, 1997.Dasar-Dasar pariwisata.Yogyakarta: CV. Andi Offset.

Tjiptono Fandy dan Gregorius Chandra. 2005. Service Quality Satisfaction. Penerbit Andi. Yogyakarta.

Tjiptono Fandy, 2007, Strategi Pemasaran. penerbit Andi, Yogyakarta. 